\title{
Extracellular-Signal Regulated Kinase Signalling Pathway Mediates the Increased Proliferation of EPCs Treated with Garlic (Allium sativum) Extract, Purple Sweet Potato (Ipomoea batatas) Extract, and Vitamin C
}

\author{
Yudi Her Oktaviono, ${ }^{1 *}$, Alisia Yuana Putri', Makhyan Jibril Al-Farabi ${ }^{1,2}$, Yesita Rizky Firmansyah ${ }^{3}$, Ferry \\ Sandra ${ }^{4,5}$
}

Yudi Her Oktaviono ${ }^{1, *}$, Alisia Yuana Putri', Makhyan Jibril Al-Farabi ${ }^{1,2}$, Yesita Rizky Firmansyah ${ }^{3}$, Ferry Sandra ${ }^{4,5}$

'Department of Cardiology and Vascular Medicine, Faculty of Medicine, Universitas Airlangga, Prof Moestopo Street 6-8, Surabaya, INDONESIA.

${ }^{2} S c h o o l$ of Management, Healthcare Entrepreneurship Division, University College London, Gower St, Bloomsbury, WC1E 6BT London, UK.

${ }^{3}$ Postgraduate School of Biomedicine, Faculty of Medicine, Brawijaya University, INDONESIA.

${ }^{4}$ Prodia Stem Cell Laboratory, Kramat $7 \mathrm{No}$ 11 Street, Jakarta, INDONESIA.

${ }^{5}$ Department of Biochemistry and Molecular Biology, Faculty of Dentistry, Universitas Trisakti, Kyai Tapa Street No.260, Jakarta, INDONESIA.

\section{Correspondence}

\section{Yudi Her Oktaviono}

Department of Cardiology and Vascula Medicine, Faculty of Medicine, Universitas Airlangga, Prof Moestopo Street 6-8, Surabaya, INDONESIA.

E-mail: yoktaviono@gmail.com

History

- Submission Date: 18-1-2020

- Review completed: 10-02-2020;

- Accepted Date: 26-02-2020

DOI : 10.5530/pj.2020.12.68

Article Available online http://www.phcogj.com/v12/i3

\section{Copyright}

(C) 2020 Phcogj.Com. This is an openaccess article distributed under the terms of the Creative Commons Attribution 4.0 International license.

\begin{abstract}
The endothelial progenitor cell (EPCs) proliferation capability is reduced in the patient with stable coronary artery disease (SCAD). Garlic (Allium sativum), purple sweet potato (Ipomoea batatas), and vitamin C are proven antioxidant which potentially improve EPCs proliferation ability. Objective: To investigate the effect of garlic (Allium sativum), purple sweet potato (Ipomoea batatas), and vitamin C in EPCs proliferation from CAD patients and identify the involvement of Extracellular-Signal Regulated Kinase (ERK) Signalling Pathway.

Material and Method: Mononuclear cells were isolated from SCAD patients and cultivated with colony-forming unit (CFU)-Hill medium and divided into untreated (control), garlic extract $(10 \mathrm{mcg} / \mathrm{ml}$ and $100 \mathrm{mcg} / \mathrm{ml})$, purple sweet potato extract $(1 \mathrm{mcg} / \mathrm{ml}$ and $25 \mu \mathrm{g} / \mathrm{ml})$, and vitamin C $(10 \mu \mathrm{g} / \mathrm{ml}$ and $250 \mu \mathrm{g} / \mathrm{ml})$. EPCs proliferation was measured using the MTT Assay. Results: This research shows that EPCs proliferation was increased in the treatment with garlic extract at $10 \mathrm{mcg} / \mathrm{ml}$ and $100 \mathrm{mcg} / \mathrm{ml}$ dose $(0.267 \pm 0,003$ and $0.391 \pm 0.008 ; p<0.05)$, purple sweet potato extract at $1 \mathrm{mcg} / \mathrm{ml}$ and $25 \mu \mathrm{g} / \mathrm{ml}$ dose $(0.250 \pm 0.005$ and $0.3562 \pm 0.023 ; p<0.001)$, and vitamin $C$ at $10 \mu \mathrm{g} / \mathrm{ml}$ and $250 \mu \mathrm{g} / \mathrm{ml}$ dose $(0.259 \pm 0.016$ and $0.306 \pm 0.022 ; p<0.001)$. Increased ERK expression was found in the treatment with garlic extract, purple sweet potato extract and vitamin C. Conclusion: Garlic extract, purple sweet potato extract, and vitamin C can increase EPC proliferation through the ERK signaling pathway.
\end{abstract}

Key words: Antioxidant, ERK, Endothelial Progenitor, Proliferation.

\section{INTRODUCTION}

Coronary artery disease is a major health problem that causes mortality and reduction of life quality worldwide. ${ }^{1}$ Endothelial progenitor cells (EPCs) from the patients with stable coronary artery disease (SCAD) had a progressive reduction of proliferation abilities, which worsen as the disease progressed ${ }^{1}$. Impaired EPCs proliferation will reduce vascular damage repair. ${ }^{2}$ Lower EPCs proliferation in the patient with SCAD is also associated with a higher incidence of cardiovascular events, mortality, and morbidity. ${ }^{3}$

Multiple pathways were suggested to be responsible for EPCs impairment in SCAD patients. It is suggested that oxidative stress play significant roles in EPCs impairment through intracellular damage and balance disruption which will alter the control of apoptosis, proliferation, self-renewal, senescence, and differentiation of EPCs. ${ }^{4-6}$ Oxidative stress may disrupt the ERK signaling pathway, which is important in EPCs proliferation. ${ }^{2,7}$ the antioxidant is suggested to have a beneficial effect on impaired EPCs proliferation from patients with cardiovascular disease. ${ }^{7,8}$
Plants with antioxidant properties such as Chokeberry (Aronia melanocarpa), ${ }^{9}$ potato shoot (Solanum tuberosum) and Marigold (Calendula officinalis) has been proven to improve impaired EPCs proliferation. ${ }^{10}$ Similarly, vitamin $\mathrm{C}$ also able to prevent lowering EPCs proliferation caused by TNF- $a .{ }^{10}$ Garlic (Allium sativum), purple sweet potato (Ipomoea batatas) extract and vitamin $\mathrm{C}$ have potent antioxidant capabilities. ${ }^{8} 11$ Previous studies also have shown purple sweet potato extract and vitamin C on the EPCs from SCAD patients and identify its mechanism. ${ }^{8}$ Hence, this research aims to identify the effect of garlic extract, purple sweet potato extract and vitamin C treatment on the EPCs and identify the involvement of ERK phosphorylation in the SCAD patient.

\section{MATERIAL AND METHODS}

Garlic extract, purple sweet potato extract, and vitamin C preparation

Garlic and Purple sweet potato were obtained from UPT Materia Medica Batu, Indonesia and vitamin C powder was obtained from Sigma-Aldrich, USA Purple sweet potato and garlic extract were produced with aqueous extraction method as described 
previously. ${ }^{12}$ The L-ascorbic acid dose referred to previous research that use dose $250 \mathrm{mcg} / \mathrm{mL}$ to improve adipocyte stem cell proliferation. ${ }^{13}$ Briefly, PSP chunks were mixed in water with a 1:1 ratio and blended. The mixture was filtered then boiled for $30 \mathrm{~min}$ and dried up using a rotary evaporator. PSP extract was diluted with the culture medium to achieve a concentration of $1 \mathrm{mcg} / \mathrm{mL}$ and $25 \mathrm{mcg} / \mathrm{mL}$. Vitamin C powder was suspended in double-distilled water and diluted with culture medium to obtain a concentration of $10 \mathrm{mcg} / \mathrm{mL}$ and $250 \mathrm{mcg} /$ $\mathrm{mL}$.

\section{Subject recruitment and sample collection}

The blood sample was obtained from eight patients with SCAD in Dr. Soetomo General Hospital with inclusion criteria as follows: male, aged 40-59, stable angina, and coronary angiography showed $>50 \%$ stenosis of left main coronary artery or $>70 \%$ of other coronary arteries. Subjects with a history of percutaneous coronary intervention, coronary artery bypass grafting, acute myocardial infarct, diabetes, smoking, and anemia were excluded. The study protocol was approved by the Health Research Ethics Committee of Dr. Soetomo General Hospital, Surabaya (No.292/Panke.KKE/IV/2016). Each subject has signed informed consent before subject recruitment.

\section{EPCs isolation and culture}

Peripheral blood mononuclear cells (PBMCs) were isolated from the blood sample by Ficoll Histopaque 1077 (Sigma-Aldrich, USA). To isolate EPCs from PBMCs, a standard protocol was conducted as described previously. ${ }^{2}$ Briefly, $5 \times 10^{5}$ cells/mL PBMCs were cultured in the fibronectin-coated 6-well plate with basal stemline II hematopoietic stem cell expansion medium (Sigma-Aldrich, USA) supplemented with $15 \%$ fetal bovine serum and $40 \mathrm{ng} / \mathrm{mL}$ vascular endothelial growth factor. The culture was maintained at $37^{\circ} \mathrm{C}$ with $5 \% \mathrm{CO}_{2}$ in a humidified atmosphere. Two days after, non-adherent cells were discarded, and fresh medium was added. Two weeks after, cultured cells were stained FITC-labeled anti-human CD34 antibody clone 581 (Biolegend, USA) and documented with an inverted immunofluorescence microscope. EPCs were confirmed from CD 34 expression.

\section{EPCs proliferation assay}

MTT cell proliferation assay kit (Sigma-Aldrich, USA) was used to measure EPCs proliferation as described previously. ${ }^{7}$ Treated EPCs were added with MTT reagent and incubated in a $37^{\circ} \mathrm{C}$ incubator with $5 \% \mathrm{CO}_{2}$ for 4 hours. Proliferation was determined from the reduction of tetrazolium (MTT) into insoluble formazan product by viable EPCs mitochondria. Absorbance was measured with a microplate reader at $595 \mathrm{~nm}$ wavelength.

\section{Western blot analysis}

The protein samples from EPCs were loaded into sodium dodecyl sulfate-polyacrylamide gel (SDS-PAGE) for electrophoresis. The electroblotting apparatus was used to transfer the protein onto the nitrocellulose membrane. The membranes were incubated with primary antibodies rabbit anti-human ERK (Sigma-Aldrich, USA) for overnight. The membrane then washed and incubated with conjugated secondary anti-rabbit IgG antibody. The result was visualized with an image analyzer.

\section{Statistical analysis}

Statistical analyses were carried out using IBM SPSS Statistics 25.0 (IBM Corp, USA). Data were compared using the ANOVA test and considered to be significantly different if $p<0.05$ or $p<0.001$.

\section{RESULTS}

\section{Demography of the subjects}

The blood samples were obtained from eight patients with SCAD and history of antihypertension and statin treatment. Demography of the subjects is shown in Table 1 .

\section{EPCs confirmation}

EPCs were confirmed by CD34 expression, the most commonly-used surface marker to identify EPCs (Benjamin et al. 2013). EPCs colony and CD34 expression can be seen in Figure 1.

\section{The effect of garlic (Allium sativum) extract, purple sweet} potato (Ipomoea batatas L.), and vitamin C on the EPC proliferation

As shown in Figure 2, under the treatment with garlic extract, purple sweet potato and vitamin $\mathrm{C}$ at all doses, the proliferation capability of EPCs was significantly higher compared to the negative control $(p<$ 0.05 , ANOVA). EPCs proliferation capability was increased in a dosedependent manner with the treatment using garlic extract, purple sweet potato extract and vitamin C. Highest EPCs proliferation capability were observed on the EPCs treated with $100 \mathrm{mg} / \mathrm{ml}$ garlic extract.

ERK expression on the EPCs treated with garlic extract, purple sweet potato extract, and vitamin C

Western blot examination showed positive expression of ERK phosphorylation at the higher dose of garlic extract, purple sweet potato extract and vitamin $C$ (Figure 3 ). This suggests that a higher dose of garlic extract, purple sweet potato extract, and vitamin $\mathrm{C}$ will increase the EPCs proliferation capability followed by increased ERK phosphorylation.

\section{DISCUSSION}

Patient with SCAD has impaired EPCs proliferation and migration capabilities. ${ }^{1,2}$ This research showed that garlic extract, purple sweet potato extract, and vitamin $\mathrm{C}$ had beneficial effects to improve the proliferation of the EPCs derived from peripheral blood of SCAD patients in a concentration-dependent manner. This finding is consistent with previous researches, which showed the ability of garlic extract, purple sweet extract benefit to improve the proliferation of several stem cell lines. Garlic extract was proven to improve neovasculogenesis in a dose-dependent manner for an animal model of neovacsculogenesis. ${ }^{14}$ Garlic extract contains a high level of allicin, which has been proven to

Table 1: Subjects demography.

\begin{tabular}{cc}
\hline Variable & Mean \pm SD \\
\hline Age (year) & $54.5 \pm 4.31$ \\
Height $(\mathrm{cm})$ & $168.0 \pm 1.3$ \\
Body Mass Index $\left(\mathrm{kg} / \mathrm{m}^{2}\right)$ & $25.39 \pm 2.13$ \\
Systolic Blood Pressure $(\mathrm{mmHg})$ & $137.5 \pm 24.35$ \\
Diastolic Blood Pressure $(\mathrm{mmHg})$ & $80.0 \pm 7.56$ \\
Heart rate (beats/min) & $86 \pm 8.68$ \\
Total Cholesterol $(\mathrm{mg} / \mathrm{dL})$ & $200.5 \pm 74.75$ \\
Triglyceride $(\mathrm{mg} / \mathrm{dL})$ & $97 \pm 11.64$ \\
LDL $(\mathrm{mg} / \mathrm{dL})$ & $145 \pm 61.11$ \\
HDL $(\mathrm{mg} / \mathrm{dL})$ & $35 \pm 7.64$ \\
LVEF $(\%)$ & $53.5 \pm 4.11$ \\
\hline
\end{tabular}

LDL: Low-Density Lipoprotein, HDL : High-Density Lipoprotein, LVEF: Left Ventricle Ejection Fraction. 


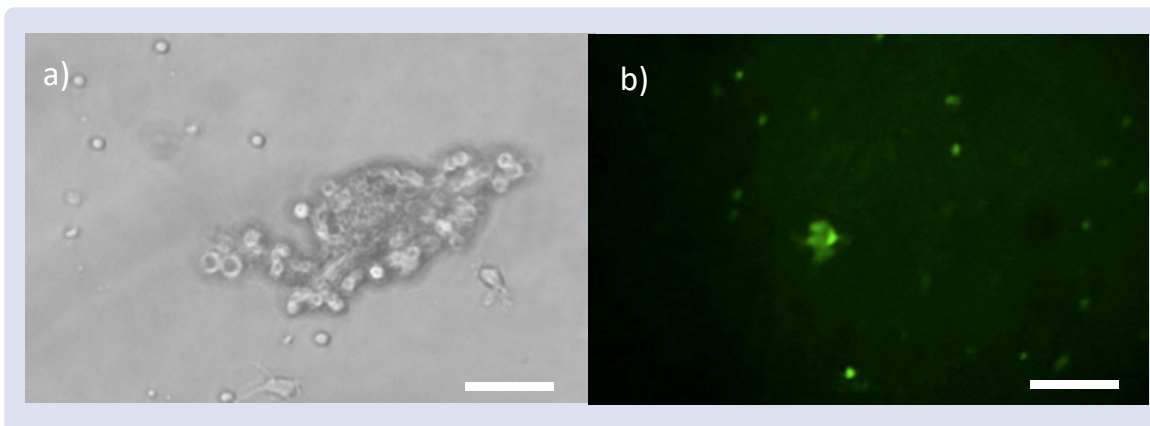

Figure 1: a) EPCs colony under 100x magnification in the inverted microscope; b Immunofluorescence view of FITC-labelled CD34 expression which confirms EPCs; White bar represents $100 \mu \mathrm{m}$.
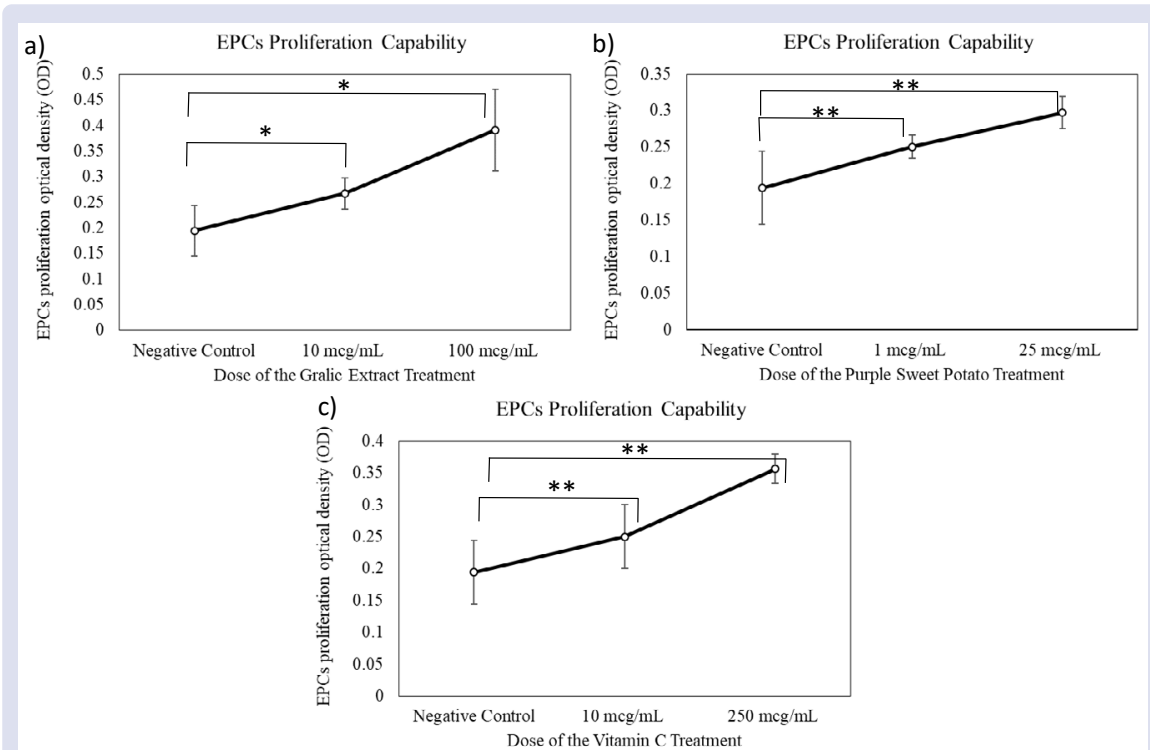

Figure 2: Garlic extract, purple sweet potato extract, and vitamin C improve EPCs proliferation in a dose-dependent manner. EPCs proliferation after treated with a) $10 \mathrm{mcg} / \mathrm{mL}$ and $100 \mathrm{mcg} / \mathrm{mL}$ garlic extract; b) $1 \mathrm{mcg} / \mathrm{mL}$ and $25 \mathrm{mcg} / \mathrm{mL}$ purple sweet potato extract; c) $10 \mathrm{mcg} / \mathrm{mL}$ and 250 $\mathrm{mcg} / \mathrm{mL}$ Vitamin C for $48 \mathrm{~h}$. EPCs proliferation was measured using MTT proliferation assay and statistically analyzed, as described in Materials and Methods. Sextuplicate was performed for each group. ${ }^{*}$ significant difference at $p<0.05 ;{ }^{* *}$ : significant difference at $p<0.001$.

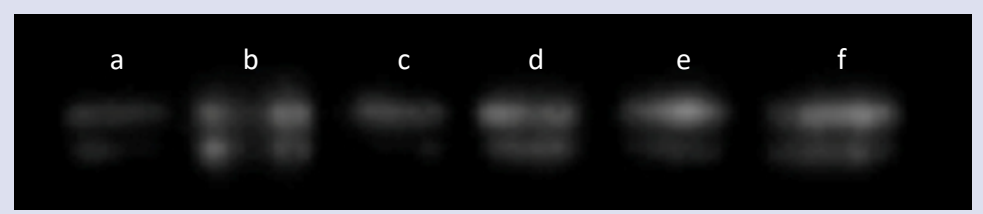

Figure 3: Garlic extract, purple sweet potato extract, and vitamin C increase ERK expression with higher doses. ERK phosporylation in the electrophoresis gel after treated with a) $10 \mathrm{mcg} / \mathrm{mL}$ garlic extract; b) $100 \mathrm{mcg} / \mathrm{mL}$ garlic extract; c) $1 \mathrm{mcg} / \mathrm{mL}$ purple sweet potato extract; d) $25 \mathrm{mcg} / \mathrm{mL}$ purple sweet potato extract; e) $10 \mathrm{mcg} /$ $\mathrm{mL}$ vitamin C; and f) $250 \mathrm{mcg} / \mathrm{mL}$ vitamin C for $48 \mathrm{~h}$.

improve EPCs proliferation and migration..$^{15}$ It is also suggested that garlic extract improves EPCs' neovasculogenesis capability through modulation of the PI3/Akt pathway. ${ }^{14}$

Purple sweet potato contains a high amount of anthocyanins, which was proven to improve impaired EPCs proliferation and migration in vivo ${ }^{16}$. High-level of anthocyanin also has been proven to increase EPCs proliferation capability in a dose-dependent manner through the reduction of intracellular ROS. ${ }^{9}$ This suggested that the benefit of purple sweet potato extract on the EPCs proliferation might involve the
ROS pathway. Interestingly, purple sweet potato showed an inhibitory effect on breast cancer, gastric cancer, bladder cancer cell, and colon adenocarcinoma proliferation $1 .{ }^{17-19}$ This suggests that purple sweet potato might both stimulate or inhibit cell proliferation depending on the type of cells.

Vitamin C treatment has been proven to improve the proliferation of adipocyte stem cells, cardiac progenitor cells, and intestinal stem cells. ${ }^{13,20,21}$ Similar to this research, vitamin C at the dose of $10 \mathrm{mcg} /$ $\mathrm{mL}$ was shown to prevent the impairment of EPCs proliferation 
caused by TNF- $\alpha$ through P38 inhibition. ${ }^{10}$ Interestingly, vitamin C at the dose of $100 \mathrm{mg} / \mathrm{dl}$ can reduce the proliferation of the EPCs and vasculogenesis. ${ }^{22}$ This suggests that dose-dependent effect of vitamin $\mathrm{C}$ to the EPCs proliferation.

In this research, the higher dose of garlic extract $(100 \mathrm{mcg} / \mathrm{mL})$, purple sweet potato extract $(25 \mathrm{mcg} / \mathrm{mL})$, and vitamin C $(100 \mathrm{mcg} / \mathrm{mL})$ were proven to increase phosphorylated ERK of the EPCs compared to the lower dose. While the exact mechanism of impaired proliferation in the EPCs in CHD patients remains unclear, it is suggested that oxidative stress may be involved in the EPCs impairment. ${ }^{5}$ Several antioxidants such as vitamin $\mathrm{E}$, resveratrol, and $\mathrm{L}$-arginine have proven to improve EPCs proliferation in-vivo and in vitro. ${ }^{10,16}$ Oxidative stress downregulates ERK signaling pathway in the embryonic stem cell. ${ }^{6}$ While ERK signal transduction pathway is responsible for promoting cell proliferation, nutrient uptake, and cell survival. ${ }^{23}$ Reduced ERK signaling pathway also has proven to reduce EPCs proliferation in patients with stable angina. ${ }^{2}$ Hence, It is speculated that the beneficial effect of the garlic extract, purple sweet extract, and vitamin $\mathrm{C}$ extract to improve EPCs proliferation may involve its antioxidant capability which increases ERK phosphorylation.

\section{CONCLUSION}

Treatment with garlic extract, purple sweet potato extract and vitamin $\mathrm{C}$ increase EPC proliferation which might involve ERK signaling pathway.

\section{ACKNOWLEDGMENT}

The authors are grateful to the staff of the Surabaya Regenerative and Stem Cell Centre who assist the laboratory works.

\section{CONFLICTS OF INTEREST}

The authors declare no conflict of interest.

\section{REFERENCES}

1. Vasa M, Ficht L, Scherer S, Aicher A, Adler K, Urbich C, et al. Number and migratory activity of circulating endothelial progenitor cells inversely correlate with risk factors for coronary artery disease. Circ Res. 2001:89:E1-E7.

2. Oktaviono $Y H$, Sargowo D, Widodo MA, Dirgantara $Y$, Chouw A, Sandra F Proliferation of Peripheral Blood-derived Endothelial Progenitor Cells from Stable Angina Subjects. Indones Biomed J. 2014:6:91-6.

3. Werner N, Wassmann S, Ahlers P, Schiegl T, Kosiol S, Link A, Walenta K, Nickenig G. Endothelial progenitor cells correlate with endothelial function in patients with coronary artery disease. Basic Res Cardiol. 2007:102(6):565-71.

4. Rehman J, Li J, Orschell CM, March KL. Peripheral blood endothelial progenitor cells are derived from monocyte/macrophages and secrete angiogenic growth factors. Circulation. 2003:107:1164-9.

5. Loomans CJ, De Koning EJ, Staal FJ, Rabelink TJ, Zonneveld AJ. Endothelial progenitor cell dysfunction in type 1 diabetes: another consequence of oxidative stress? Antioxid Redox Signal. 2005:7(11-12):1468-75.
6. Cieślar PA, Yue J, Lee HC, Skonieczna M, Wei YH. ROS and Oxidative Stress in Stem Cells. Oxid Med Cell Longev. 2017:5047168.

7. Lucchesi D, Russo R, Gabriele M, Longo V, Del Prato S, Penno G, et al. Grain and bean lysates improve function of endothelial progenitor cells from human peripheral blood: involvement of the endogenous antioxidant defenses. PLoS One. 2014:9(10)

8. Bong JK, Sung SH, Ji HH, Soo NP. Antioxidant Activities of Ipomoea batatas L. (Purple Sweet Potato) Extracts Cultured in Korea. Journal of the Society of Cosmetic Scientists of Korea. 2014:40:423-30.

9. Parzonko A, Oświt A, Bazylko A, Naruszewicz M. Anthocyans-rich Aronia melanocarpa extract possesses ability to protect endothelial progenitor cells against angiotensin $\|$ induced dysfunction. Phytomedicine. 2015:15;22(14):1238-46.

10. Fiorito C, Rienzo M, Crimi E, Rossiello R, Balestrieri ML, Casamassimi A, et al Antioxidants increase number of progenitor endothelial cells through multiple gene expression pathways. Free Radic Res. 2008:42 (8):754-62.

11. Hao C, Gangliang H. Extraction, characterisation and antioxidant activity of Allium sativum polysaccharide. International Journal of Biological Macromolecules. 2018:114:415-9.

12. Jawi I, Indrayani W, Arijana I, Subawa A, Suprapta D. Aqueous extratc of purole sweet potato increased SOD-2 and SOD-3 expression on human umbilical vein endothelial cells in vitro. J Biol Agric Health. 2016:6(2):103-10.

13. Yu J, Tu YK, Tang YB, Cheng NC. Stemness and transdifferentiation of adiposederived stem cells using L-ascorbic acid 2-phosphate-induced cell sheet formation. Biomaterials. 2014:35(11):3516-26.

14. Chiang EP, Chiu SC, Pai MH, Wang YC, Wang FY, Kuo YH, Tang FY. Organosulfur garlic compounds induce neovasculogenesis in human endothelial progenitor cells through a modulation of MicroRNA 221 and the PI3-K/Akt signaling pathways. J Agric Food Chem. 2013:22;61(20):4839-49.

15. Zhang FX, He CYL, Cheng GL, Wang SG. Effect of allicin on proliferation activity and migration ability of human peripheral blood endothelial progenitor cells. Chinese Journal of Biologicals. 2014;27(2):202-6.

16. Balestrieri ML, Schiano C, Felice F, Casamassimi A, Balestrieri A, Milone L, et al. Effect of low doses of red wine and pure resveratrol on circulating endothelial progenitor cells. J Biochem. 2008:143:179-86.

17. Sugata $M$, Lin CY, Shih YC. Anti-inflammatory and anticancer activities of Taiwanese purple-fleshed sweet potatoes (Ipomoea batatas) extracts. Biomed Res Int. 2015:768093.

18. Xiaoling L, Min S, Lei H, Tao W, Huanjiao Z, Chao W. Purple Sweet Potato Anthocyanin Inhibits the Proliferation of Human Retinal Pigment Epithelial Cell by Blocking Cell Cycle and Inducing Apoptosis. Advance Journal of Food Science and Technology. 2016:11(8):561-9.

19. LiWL, Yu HY, Zhang XJ, Ke M, Hong T. Purple sweet potato anthocyanin exerts antitumor effect in bladder cancer. Oncol Rep. 2018:40(1):73-82.

20. Cao N, Liu Z, Chen Z, Wang J, Chen T, Zhao X, et al. Ascorbic acid enhances the cardiac differentiation of induced pluripotent stem cells through promoting the proliferation of cardiac progenitor cells. Cell Research. 2012:22(1):219-36.

21. Mohamed MS, Chen Y, Yao CL. A serum-free medium developed for in vitro expansion of murine intestinal stem cells. Biotechnology Journal. 2014:9(7):96270.

22. Mikirova NA, Ichim TE, Riordan NH. Anti-angiogenic effect of high doses of ascorbic acid. J Transl Med. 2005:6:50.

23. Cantley LC. The phosphoinositide 3-kinase pathway. Science. 2002:296:1655-7. 


\section{GRAPHICAL ABSTRACT}

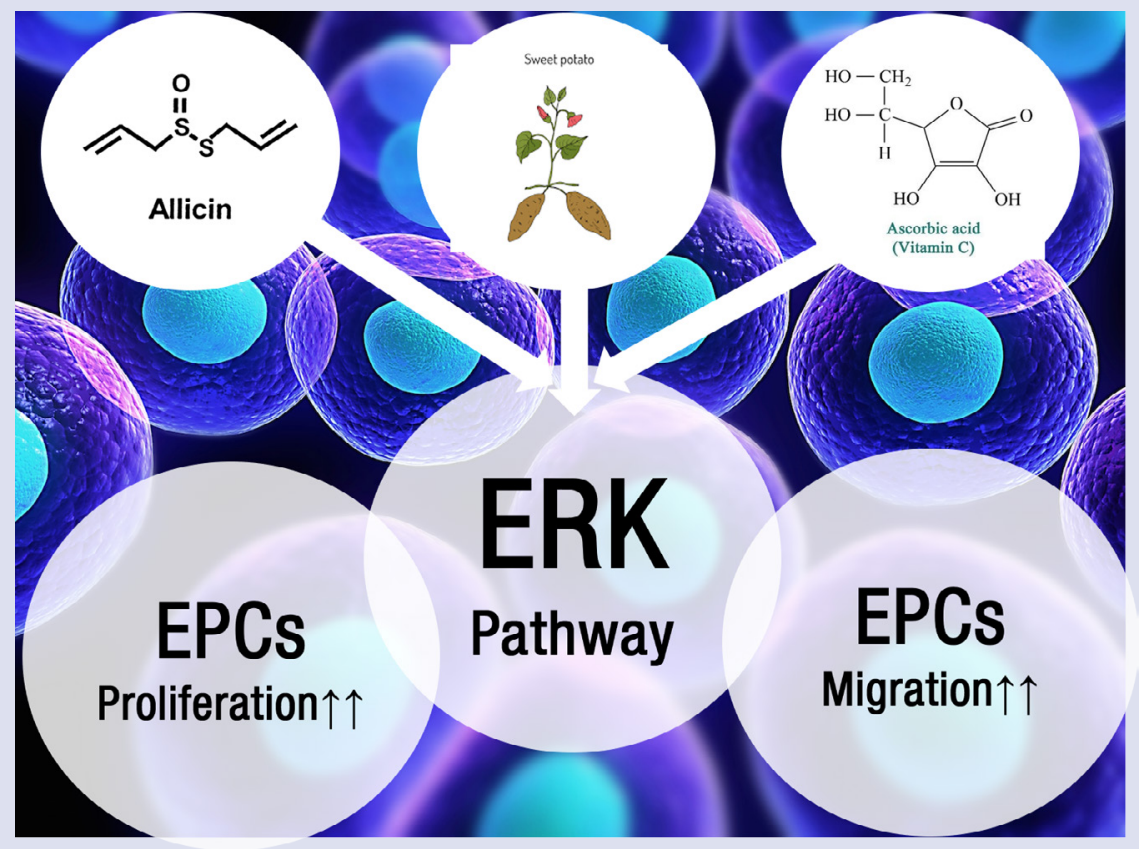

\section{ABOUT AUTHORS}

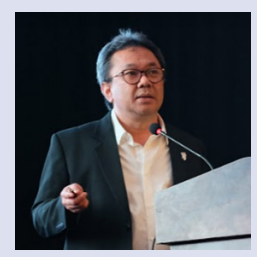

Yudi Her Oktaviono work as an interventional cardiologist in the Department of Cardiology and Vascular Medicine Soetomo General Hospital and Faculty of Medicine, University of Airlangga. Previously, He led the Indonesian Cardiologist association in Surabaya and currently he is the vice president of the Indonesian Cardiologist association. His research interests include complex interventional cardiology, endothelial progenitor stem cells, usage of natural compound for cardiac disease and detection of early cardiac markers.

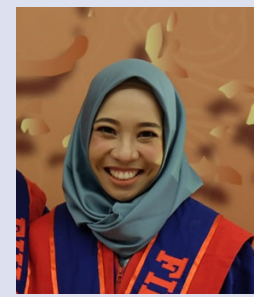

Alisia Yuana Putri work as a cardiologist in the Department of Cardiology and Vascular Medicine Soetomo General Hospital and Faculty of Medicine, University of Airlangga and Manyar Medical Center. Her research interests endothelial progenitor stem cells and cardiology risk in surgery.

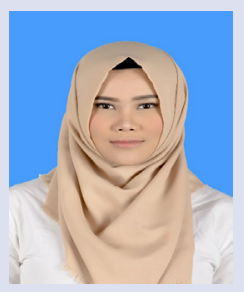

Yesita Rizky Firmansyah Putri is a medical doctor which currently work as Trust Grade Doctor of Neurosciences at University Hospital Coventry and Warwickshire, UK. She had postgraduate degree in Biomedicine from Brawijaya University. Her research interests are Clinical Cardiology and Neurology.

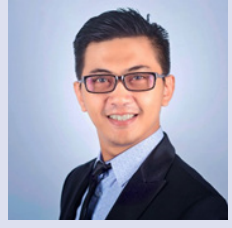

Makhyan Jibril Al-Farabi is a cardiology resident in the Department of Cardiology and Vascular Medicine Soetomo General Hospital and Faculty of Medicine, University of Airlangga. He also have postgraduate degree from University College London, Quantics School of Business and Technology and Brawijaya University. His research interests includes stem cells, clinical cardiology, cardiometabolic syndrome, healthcare entrepreneurship and Al in cardiology. 


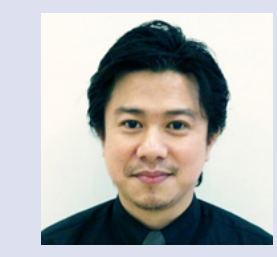

Ferry Sandra is a professor in the Department of Biochemistry and Molecular Biology Dental Faculty, Trisakti University Jakarta. He is also responsible to led the the BioCORE Laboratory. Previously, he was the director of Stem Cells and Cancer Institute (SCI). His research interests includes stem cells, cancer, inflammation and dentistry.

Cite this article: Oktaviono YH, Putri AY, Al-Farabi MJ, Firmansyah YR, Sandra F. Extracellular-Signal Regulated Kinase Signalling Pathway Mediates the Increased Proliferation of EPCs Treated with Garlic (Allium sativum) Extract, Purple Sweet Potato (Ipomoea batatas) Extract, and Vitamin C. Pharmacog J. 2020;12(3):442-7. 